\title{
Monitoring of Aphids by Suction Traps
}

Jana Patočková

Monitoring of Aphids by Suction Traps. - Čas. Slez. Muz. Opava (A), 60: 48-56, 2011.

\begin{abstract}
This study is devoted to the analysis of statistical data monitoring various aphid species by two distinct traps - suction trap and Lamber's pan trap. As cereals form the most abundant agricultural crop in the Czech Republic the study is focused on the cereal aphids. We primarily investigated following cereal aphid species: bird cherry-oat aphid (Rhopalosiphum padi Linnaeus, 1758), rose-grain aphid (Metopolophium dirhodum Walker, 1849), English grain aphid (Sitobion avenae Fabricius, 1775), and Russian wheat aphid (Diuraphis noxia Kurdjumov, 1913). Marginally, we also included three potato aphid species (Aphis nasturtii Kaltenbach, 1843, Myzus persicae Sulzer, 1776 and Phorodon humuli Schrank, 1801) into the study. Several aspects of aphid life cycle as abundance, flight activity and their migration have been examined in details. We identified the invasion behaviour for cereal aphids with recognized primary migration during the end of June. The applied analysis of the sum of effective temperatures (SET) for first cereal aphid catches revealed the bird cherry-oat aphid (Rhopalosiphum padi Linnaeus, 1758) as the aphid species requiring lower $S E T$ for their first catch $(S E T=126.2)$. There was no correlation concerning the altitude, i.e. the location of primary data collection, found within the used data set. Key words: cereal aphids, potato aphids, suction trap, Lamber's pan trap, sum of effective temperatures
\end{abstract}

\section{Introduction}

There are approximately 4700 aphid species in the world according to Remaudière \& Remaudière (1997). Blackman \& Eastop (2000) showed that ca. 450 species live on agricultural crops but only around 100 aphid species affect crop yields significantly. The aphids influence the yields by damaging plant tissue and transferring various plant virus diseases (e.g. Barley yellow dwarf virus - PAV, cereal yellow dwarf virus - RPV). Cereals damage by aphids is usually demonstrated by creation of yellow stains, twisting and drying of plant leaves and by serious decrease of grain quality and weight as documented by Reese et al. (1994). Aphids cause damage to plants by puncturing plant stems and stalks with their stilets, which are powerful suction devices built into their mouths. Once they are able to reach the plant sap they extract as much as possible, which over time can effectively weaken the plant, especially in the case of a widespread aphid infestation. Common signs of aphid damage on a plant include curled, deformed and discoloured leaves. Waste product of aphid digestion containing large amounts of saccharides limits the photosynthesis and supports development of saprophytic bacteria. Therefore the understanding of the aphid behaviour forms a crucial step for optimization of the crops and prevention of the agricultural wealth.

Since cereals are the most extensively grown agricultural crops in the Czech Republic as shown by Nedomová \& Milotová (2004) this study focuses on aphids that parasiting on them. In particular, these are bird cherry-oat aphid (Rhopalosiphum padi), rose-grain aphid (Metopolophium dirhodum), English grain aphid (Sitobion avenae), and Russian wheat aphid (Diuraphis noxia). The plant damage extent is tightly bound to the aphid population that was monitored by suction traps. The abundance captured by the traps was analysed in terms of weather and geographical conditions (temperature, altitude). The study was further extended by analysing the population of potato aphids using both suction traps and Lamber's pan traps. The suction traps are usually placed on open space while standard Lamber's pan traps location is inside the vegetation. Thus the second aim was to try to identify possible relationship between abundances detected by both trap types. This relationship might be useful for enhancing prediction by either suction or Lamber's pan trap. 


\section{Materials and Methods}

The monitoring of aphids was performed by a suction trap in five locations of the Czech Republic: Čáslav, Chrlice u Brna, Lípa u Havlíčkova Brodu, Věrovany u Olomouce, and Žatec. The suction trap used is based on Johnson-Taylor construction by Taylor (1962) modified for Rothamsted insect survey by Macaulay et al. (1988). The aphids were collected daily from April $1^{\text {st }}$ to November $30^{\text {th }}$ between 1999 and 2010 at the premises of Central Institute for Supervising and Testing in Agriculture (ÚKZÚZ). The institute provided also the weather conditions under which the collections were performed. The data from 1999 to 2006 were retrieved from the State Phytosanitary Administration (SRS) archive while the rest of data set was collected by the author.

The insect was trapped into small bottles containing 70\% denatured spirit. Samples were collected daily at 10 a.m. The aphids were separated from the other insect species and prepared for maceration. They were placed overnight into $10 \% \mathrm{KOH}$ for fat extraction. The following morning the macerated samples were rinsed 3-4 times with distilled water and transferred to a Petri dish. 60\% lactic acid was used to discolor the aphids for easier manual species determination by optical OLYMPUS binoculars. The analysis was subjected to four aphid species: bird cherry-oat aphid (Rhopalosiphum padi), rose-grain aphid (Metopolophium dirhodum), English grain aphid (Sitobion avenae), Russian wheat aphid (Diuraphis noxia).

The aphid capture was evaluated according to thermal characteristics by Honěk \& Kocourek (1990). The lower threshold for development $\left(\mathrm{T}_{\mathrm{LTD}}\right)$ adopted from the work was: 3.2 for Rhopalosiphum padi, 0.9 for Metropolophium dirhodum, 2.0 for Sitobion avenae, and 2.9 for Diuraphis noxia. The daily effective temperature is calculated from the value of lower threshold for development and the daily average temperature ( $\left.\mathrm{T}_{\text {average }}\right)$ according to

$\mathrm{ET}_{\text {LTD }}=\mathrm{T}_{\text {average }}-\mathrm{T}_{\mathrm{LTD}}$

The daily average temperature is calculated from temperature extremes according to $\mathrm{T}_{\text {average }}=\left(\mathrm{T}_{\max }+\mathrm{T}_{\min }\right) / 2$

The sum of effective temperatures (SET) is calculated as the total sum of individual values of effective temperature from January $1^{\text {st }}(i=1)$ to a given date (day $\left.n\right)$.

$5 E T_{\text {LTR }}=\sum_{i=1}^{n} E T_{L F D}$

where meeting the condition $\mathrm{T}_{\text {average }}>\mathrm{T}_{\mathrm{LTD}}$.

The raw, observed data were statistically evaluated by statistical program R 2.13.0. Program METEODAT 1.30 was used for calculation of SET, while program Gnuplot 4.4.3 was used for preparation of plots.

The work was further extended by studying of both cereal and potato aphids at Lípa u Havlíčkova Brodu. The aphid catches were performed from the beginning of June up to the end of August. The aim of this extension was to evaluate the performance of suction and Lamber's pan traps. The following aphid species were analyzed according the procedure described above: bird cherry-oat aphid (Rhopalosiphum padi), rose-grain aphid (Metopolophium dirhodum), English grain aphid (Sitobion avenae), Russian wheat aphid (Diuraphis noxia), Buckthorn aphid (Aphis nasturtii), peach - potato aphid (Myzus persicae), and damson - hop aphid (Phorodon humuli). The correlation between aphid abundance collected by both traps was analyzed by linear regression analyses using statistical package Statistica 8.0. The correlation is expressed as coefficient of determination $\mathrm{R}^{2}$.

The standard linear regression model was used $\mathrm{n}(\mathrm{ST})=\mathrm{a} * \mathrm{n}(\mathrm{LPT})+\mathrm{b}$

where $n$ is abundance aphids of suction trap $(S T)$ and Lamber's pan trap $(L P T)$. The used regression model expected dependency between aphid abundances obtained from different types of deployed traps.

\section{Results and Discussions}

\section{Comparison of suction trap versus Lamber's pan trap}

In the beginning, the comparison of the performance for both traps (localized in potato vegetation) has been analysed. The acquired data for the time period 1999-2010 in Lípa $u$ Havličckova Brodu (from the beginning of June up to the end of August) are summarized in Table 1 together with the linear regression models. According to the regression parameter $a$ the results show that suction trap has approximately 10 up to 20 times higher efficiency in aphid trapping compared to the Lamber's pan trap. The obtained results also indicate that two species, namely Metopolophium dirhodum and Sitobion avenae, has higher traps correlation compared to the others. Since the Lamber's pan trap has yellow colour and suction traps are uncoloured we might conclude that these higher correlations are caused by the higher attraction to the yellow colour by these two species. The best correlations for Metopolophium dirhodum and Sitobion avenae are shown in Figure 1. 
Tab 1: Comparison of trap types for cereal aphids (LPT - year aphid abundance by Lamber's Pan Trap, ST year aphid abundance by Suction Trap)

\begin{tabular}{|c|c|c|c|c|c|c|c|c|}
\hline species & \multicolumn{2}{|c|}{ Diuraphis noxia } & \multicolumn{2}{|c|}{ Metopolophium dir. } & \multicolumn{2}{|c|}{ Rhopalosiphum padi } & \multicolumn{2}{|c|}{ Sitobion avenae } \\
\hline year & LPT & ST & LPT & ST & LPT & $\mathrm{ST}$ & LPT & ST \\
\hline 1999 & 3 & 31 & 66 & 304 & 26 & 326 & 5 & 156 \\
\hline 2000 & 14 & 64 & 6 & 210 & 46 & 2071 & 15 & 681 \\
\hline 2001 & 5 & 284 & 1 & 15 & 8 & 292 & 1 & 94 \\
\hline 2002 & 4 & 80 & 55 & 729 & 74 & 3556 & 16 & 322 \\
\hline 2003 & 1 & 94 & 69 & 448 & 38 & 1267 & 48 & 1399 \\
\hline 2004 & 2 & 27 & 2 & 59 & 8 & 1219 & 5 & 391 \\
\hline 2005 & 5 & 115 & 136 & 2603 & 23 & 2248 & 60 & 1959 \\
\hline 2006 & 1 & 123 & 6 & 128 & 29 & 500 & 8 & 46 \\
\hline 2007 & 8 & 820 & 4 & 6 & 11 & 316 & 0 & 50 \\
\hline 2008 & 4 & 20 & 6 & 14 & 49 & 2158 & 4 & 164 \\
\hline 2009 & 0 & 5 & 52 & 288 & 91 & 915 & 79 & 814 \\
\hline 2010 & 0 & 0 & 77 & 102 & 119 & 733 & 18 & 86 \\
\hline$a$ & \multicolumn{2}{|c|}{21.4} & \multicolumn{2}{|c|}{13.6} & \multicolumn{2}{|c|}{7.0} & \multicolumn{2}{|c|}{18.3} \\
\hline$b$ & \multicolumn{2}{|c|}{54.7} & \multicolumn{2}{|c|}{-133.6} & \multicolumn{2}{|c|}{995.2} & \multicolumn{2}{|c|}{119.4} \\
\hline $\mathrm{R}^{2}$ & \multicolumn{2}{|c|}{0.14} & \multicolumn{2}{|c|}{0.65} & \multicolumn{2}{|c|}{0.06} & \multicolumn{2}{|c|}{0.61} \\
\hline
\end{tabular}
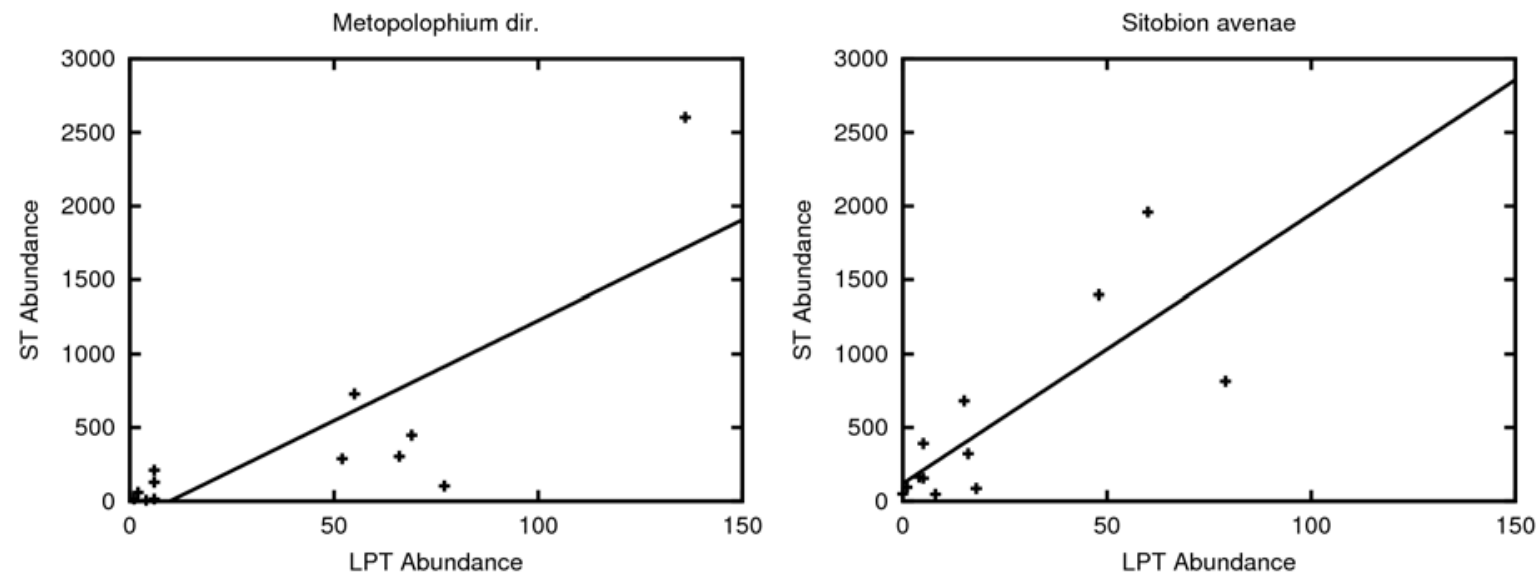

Fig 1: Selected abundance correlations for tested traps and selected cereal aphids

The same analyse has been performed for a set of potato aphids data. Due to limited abundance we did not try to distinguish among different potato aphid species. The obtained results demonstrate the higher efficiency of the Lamber's pan trap as listed in Table 2 and shown in Figure 2. The reason is probably the fact that in this case the Lamber's pan trap has been located directly inside the potato vegetation which led to comparable aphid catches in both traps. 
Tab 2: Comparison of trap types for potato aphids (LPT - year aphid abundance by Lamber's Pan Trap, ST year aphid abundance by Suction Trap)

\begin{tabular}{c|cc} 
& \multicolumn{2}{|c}{ potato aphids } \\
\hline \hline year & LPT & ST \\
\hline 1999 & 204 & 165 \\
2000 & 57 & 25 \\
2001 & 167 & 155 \\
2002 & 85 & 124 \\
2003 & 42 & 46 \\
2004 & 183 & 287 \\
2005 & 136 & 132 \\
2006 & 95 & 157 \\
2007 & 61 & 145 \\
2008 & 81 & 115 \\
2009 & 116 & 83 \\
2010 & 176 & 156 \\
\hline$a$ & \multicolumn{2}{|c}{0.8} \\
$b$ & \multicolumn{2}{|c}{34.0} \\
$\mathrm{R}^{2}$ & & 0.49 \\
& &
\end{tabular}

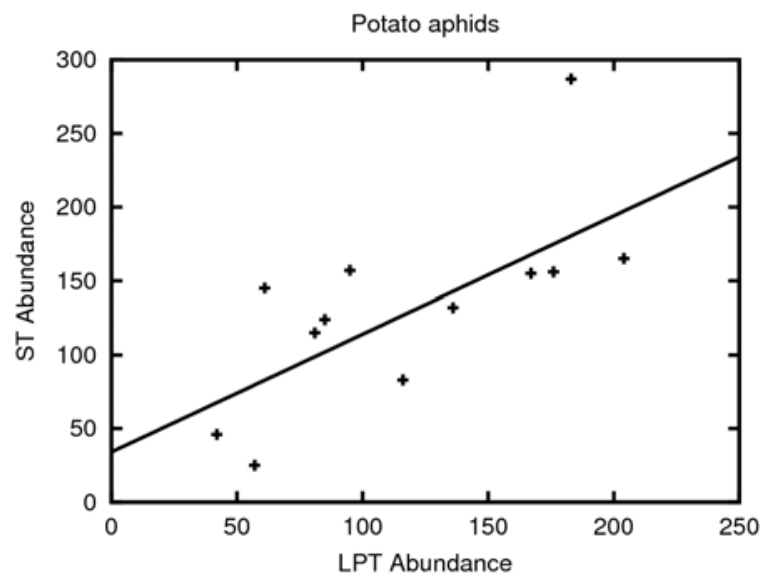

Fig 2:. Abundance correlation for tested traps and potato aphids

\section{Aphid flight activity}

The aphid flight activity has been studied by monitoring the aphid abundance during the time period 1999-2010. A location Verrovany has been selected as a use case due to largest aphid catches. The migration data are shown in Figure 3. The obtained plots display the typical aphid migration behaviour. The aphid migration starts at the end of May due to increase of outside temperature. Within 2-3 weeks the invasion reaches the maximum and subsequently the amount of aphids decreases. The flight activity decreases during summer which is caused by temperature exceeding $25^{\circ} \mathrm{C}$. Later in September the autumn aphid flow starts and it reaches the second maximum around October.

Basky \& Harrington (2000) have collected and analysed the cereal aphid migration data in Hungary and UK using the Johnson-Taylor suction traps. They proved that the first invasion and the migration peek of aphids occur 1-3 weeks earlier in Szolnok (Hungary) compared to 
Rothamsted (UK). This is caused by earlier start of vegetation season in warmer Hungary in comparison to UK. Our results indicate that the first aphid invasion peak at selected location in the Czech Republic arrives at week 26 that corresponds to the end of June. The direct comparison with data available in freely accessible archive Rothamsted Insect Survey listed in Aphid Bulletin confirms that invasion peak maximum in UK generally appears during at week 28 corresponding to the half of July (exactly two weeks later than in the Czech Republic).
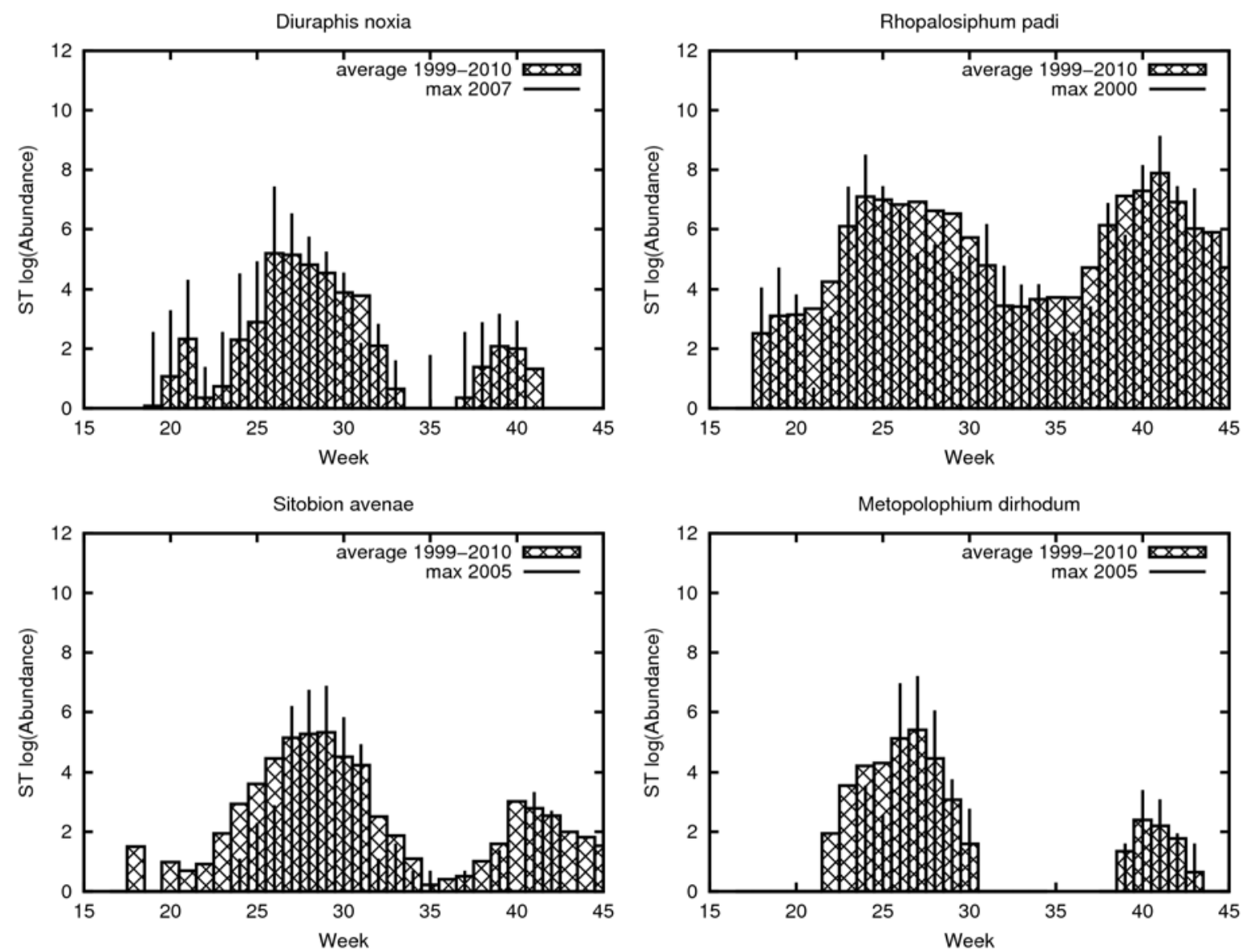

Fig 3: Aphid flight activity at Verovany location

\section{Evaluation of sums of effective temperatures}

Next step was the evaluation of obtained values of sum of effective temperatures. The sum of effective temperatures was calculated using the daily temperatures and the lower threshold for the development of the individual aphid species. The collected data are summarized in Table 3. The table contains SET values for following aphid species: Rhopalosiphum padi, Metopolophium dirhodum, Sitobion avenae, and Diuraphis noxia acquired at five different locations from 2006 to 2010. The analysis indicates that the sum of effective temperatures is strongly influenced by the aphid species and the observation year as shown in Figure 4. The differences at individual locations or the influence of the altitude cannot be proven. However, the data collected for a specific aphid species can be used for aphid species distinction as outlined in Figure 5. Three out of four aphid species require for their proper development higher SET while the life cycle of Rhopalosiphum padi has an early start compared to the other aphid species.

Observed data in Table 3 allows the identification of the SET minima that corresponds to the first aphid generation caught by the suction traps. Honěk \& Kocourek (1990) report the value required for the development of the first aphid generation as $S E T=128$. Our results 
indicate that the minimal value corresponding to the first generation development is approximately $S E T=126.2$ (as the average from three minimal values - all three for Rhopalosiphum padi).

Based on investigation of Juroch (2010) who built a temperature model for codling moth our intention was to use obtained SET data for building a similar temperature model for aphids. Unfortunately, due to the fact that the days when first catch is performed differ for various years, it is impossible to build such a model.

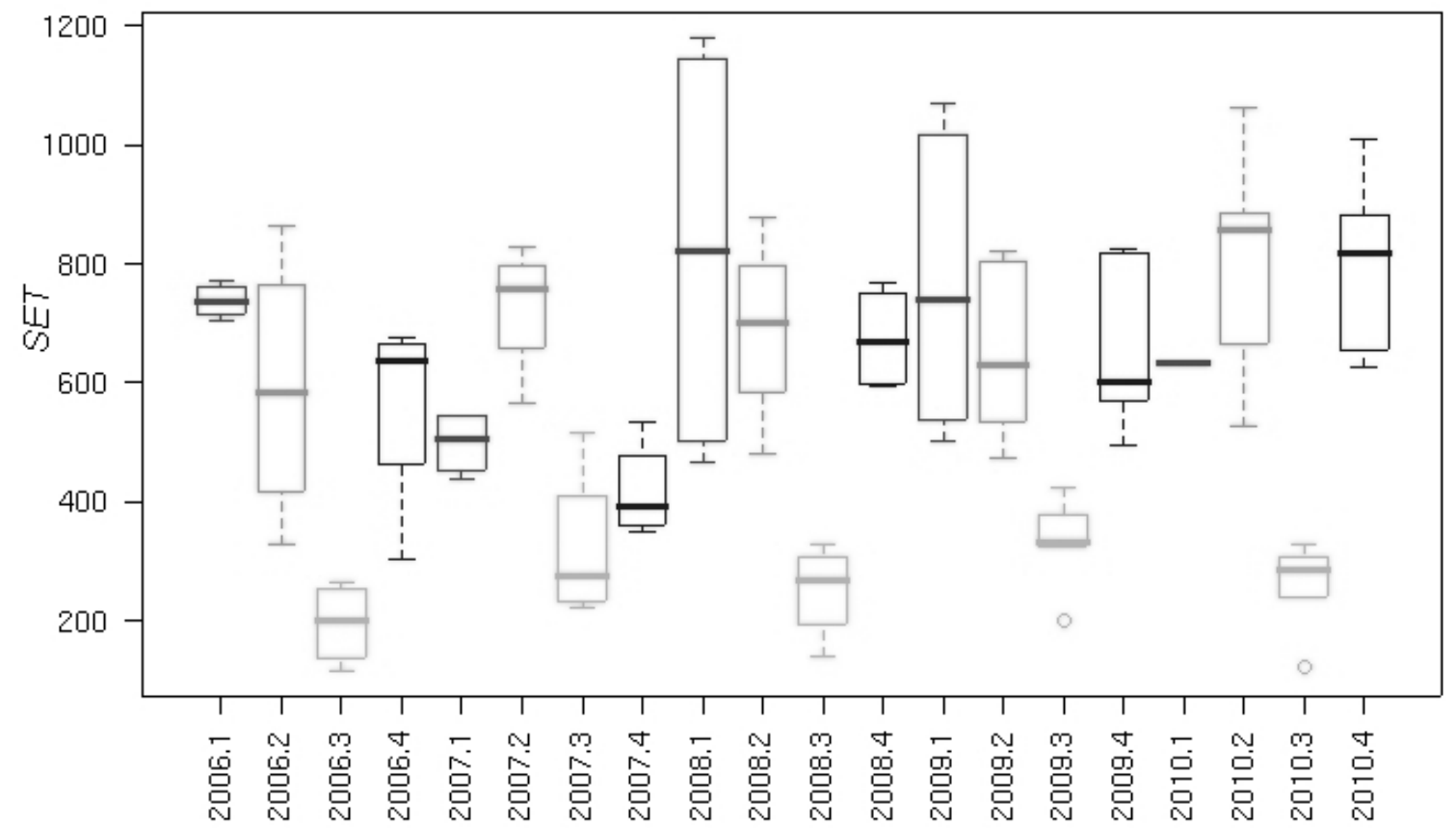

Fig 4: Boxplots for SET during first aphid catch (median is indicated by colour line, box contains $75 \%$ of raw values). The data are sorted according to year.species: year $=$ observation years and species $=1-$ Diuraphis noxia, 2 -Metopolop. dirhodum, 3 - Rhopalosiphum padi, and 4 - Sitobion avenae. .

Tab 3: Summary of the first cereal aphid catches 


\begin{tabular}{|c|c|c|c|c|c|c|c|c|c|}
\hline \multirow{2}{*}{$\begin{array}{l}\text { Location } \\
\text { Aphids } \\
\end{array}$} & \multicolumn{3}{|c|}{$\begin{array}{l}\text { ČÁSLAV } \\
\text { ordinal }\end{array}$} & \multicolumn{3}{|c|}{$\begin{array}{c}\text { CHRLICE U BRNA } \\
\text { ordinal }\end{array}$} & \multicolumn{3}{|c|}{$\begin{array}{c}\text { LÍPA U HAVLÍČKOVA } \\
\text { BRODU } \\
\text { ordinal }\end{array}$} \\
\hline & first catch & day & SET & first catch & day & SET & first catch & day & SET \\
\hline \multirow{5}{*}{ 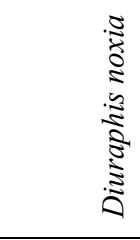 } & 18.6.2006 & 169 & 722.2 & 15.6.2006 & 166 & 704.4 & 24.6 .2006 & 175 & 773.1 \\
\hline & 11.5.2007 & 131 & 534.3 & 18.5.2007 & 138 & 544.3 & 11.5 .2007 & 131 & 439.1 \\
\hline & 3.7 .2008 & 185 & 1179.0 & 18.5.2008 & 139 & 538.1 & 27.5.2008 & 148 & 468.1 \\
\hline & 25.6.2009 & 176 & 1018.0 & 9.5 .2009 & 129 & 501.3 & 15.6.2009 & 166 & 739.5 \\
\hline & 2010 & & 0 & 2010 & & 0 & 2010 & & 0 \\
\hline \multirow{5}{*}{ 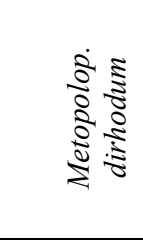 } & 16.6.2006 & 167 & 863.3 & 3.5 .2006 & 123 & 328.5 & 7.6.2006 & 158 & 664.6 \\
\hline & 10.5 .2007 & 130 & 747.8 & 22.5.2007 & 142 & 828.8 & 21.5.2007 & 141 & 765.5 \\
\hline & 16.5 .2008 & 137 & 689.1 & 16.5 .2008 & 137 & 712.1 & 11.5 .2008 & 132 & 480.1 \\
\hline & 24.5.2009 & 144 & 822.7 & 7.5.2009 & 127 & 629.6 & 5.6.2009 & 156 & 802.9 \\
\hline & 22.5.2010 & 142 & 665.1 & 14.6.2010 & 165 & 1064 & 15.6.2010 & 166 & 855.5 \\
\hline \multirow{5}{*}{ 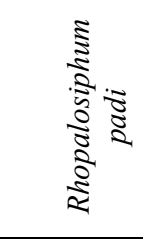 } & 18.4 .2006 & 108 & 115.9 & .5 .2006 & 124 & 245.3 & 11.5 .2006 & 131 & 263.2 \\
\hline & 9.4 .2007 & 99 & 220.4 & 18.5 .2007 & 138 & 514.6 & 20.4 .2007 & 110 & 244.6 \\
\hline & 4.5.2008 & 125 & 327.0 & 28.4.2008 & 119 & 286.9 & 6.5.2008 & 127 & 247.1 \\
\hline & 14.4.2009 & 104 & 199.6 & 4.5.2009 & 124 & 425.3 & 8.5.2009 & 128 & 331.4 \\
\hline & 1.5.2010 & 121 & 308.0 & 3.5 .2010 & 123 & 328.2 & 6.5 .2010 & 126 & 239.6 \\
\hline \multirow{5}{*}{ 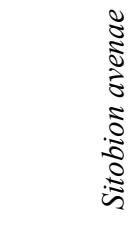 } & 9.6 .2006 & 160 & 651.2 & 5.5.2006 & 125 & 305.0 & 11.6 .2006 & 162 & 622.6 \\
\hline & 2.5.2007 & 122 & 535.6 & 23.4 .2007 & 113 & 367.4 & 23.4 .2007 & 113 & 350.4 \\
\hline & 31.5.2008 & 152 & 769.7 & 16.5.2008 & 137 & 594.5 & 30.5 .2008 & 151 & 603.5 \\
\hline & 16.5.2009 & 136 & 600.5 & 9.5 .2009 & 129 & 568.2 & 15.6.2009 & 166 & 824.7 \\
\hline & 9.6 .2010 & 160 & 819.5 & 18.6 .2010 & 169 & 1009.0 & 26.6 .2010 & 177 & 880.6 \\
\hline
\end{tabular}

\begin{tabular}{|c|c|c|c|c|c|c|}
\hline $\begin{array}{l}\text { Location } \\
\text { Aphids } \\
\end{array}$ & \multicolumn{3}{|c|}{$\mid \begin{array}{c}\text { VĚROVANY U OLOMOUCE } \\
\text { ordinal }\end{array}$} & \multicolumn{3}{|c|}{$\begin{array}{l}\text { ŽATEC } \\
\text { ordinal }\end{array}$} \\
\hline \multirow{5}{*}{ 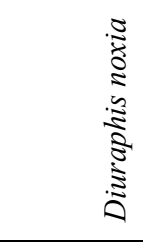 } & 16.6 .2006 & 167 & 750.6 & 22.5.2006 & 142 & 553.4 \\
\hline & 7.5.2007 & 127 & 464.4 & 4.5 .2007 & 124 & 554.3 \\
\hline & 28.6 .2008 & 180 & 1107.0 & 2.7 .2008 & 184 & 1324.0 \\
\hline & 16.5.2009 & 136 & 535.9 & 25.6.2009 & 176 & 1068.0 \\
\hline & 4.6.2010 & 155 & 633.2 & 2010 & & 0 \\
\hline \multirow{5}{*}{ 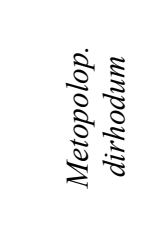 } & 16.5 .2006 & 136 & 504.8 & 12.6 .2006 & 142 & 975.4 \\
\hline & 27.4 .2007 & 117 & 567.1 & 23.5 .2007 & 143 & 1066 \\
\hline & 30.5 .2008 & 151 & 879.8 & 7.5.2008 & 128 & 639.0 \\
\hline & 3.5 .2009 & 123 & 534.9 & 26.4.2009 & 116 & 474.5 \\
\hline & 11.5 .2010 & 131 & 528.1 & 8.6.2010 & 159 & 883.9 \\
\hline \multirow{5}{*}{ 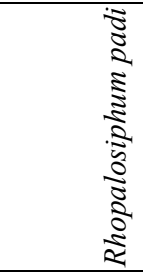 } & 24.4 .2006 & 114 & 158.6 & 8.5 .2006 & 128 & 345.5 \\
\hline & 23.4.2007 & 113 & 304.5 & 26.4.2007 & 116 & 437.4 \\
\hline & 9.4 .2008 & 100 & 141.7 & 5.5 .2008 & 126 & 393.9 \\
\hline & 28.4.2009 & 118 & 325.5 & 30.4 .2009 & 120 & 376.6 \\
\hline & 1.5 .2010 & 121 & 284.2 & 7.4.2010 & 97 & 121.0 \\
\hline \multirow{5}{*}{ 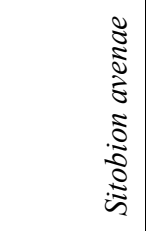 } & 6.6 .2006 & 157 & 677.5 & 6.6 .2006 & 157 & 774.5 \\
\hline & 24.4.2007 & 114 & 417.5 & 28.4 .2007 & 118 & 592.0 \\
\hline & 29.5.2008 & 150 & 730.9 & 14.5.2008 & 135 & 637.6 \\
\hline & 7.5.2009 & 127 & 494.6 & 28.5.2009 & 148 & 819.5 \\
\hline & 30.5 .2010 & 150 & 655.5 & 28.5.2010 & 148 & 627.1 \\
\hline
\end{tabular}




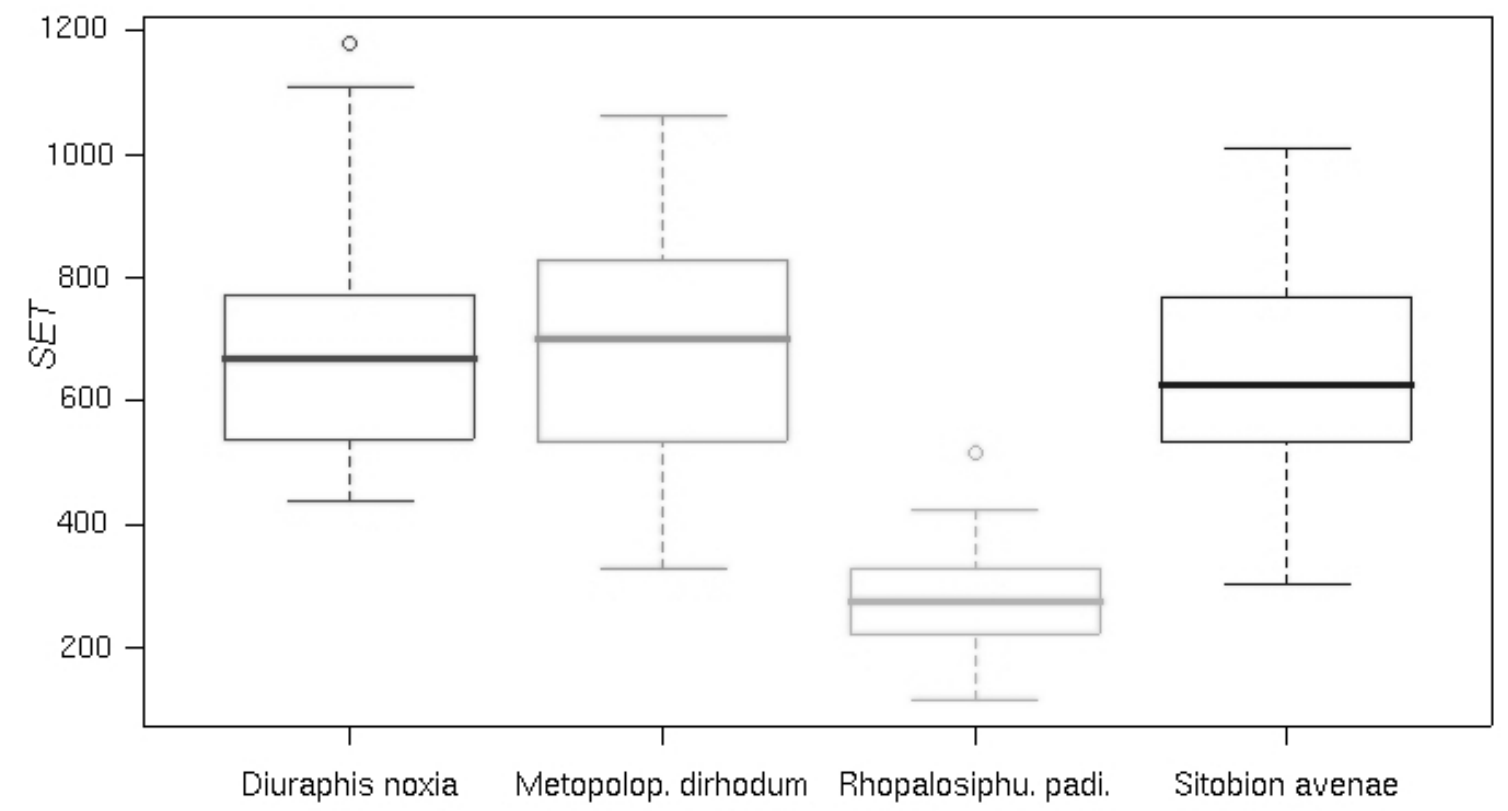

Fig 5: Boxplots for SET during first aphid catch summarized (5 years) for specific aphid species.

\section{Conclusions}

This study was devoted to the monitoring of aphids in three main topics. Firstly, the comparison of different aphid trapping techniques was performed for cereal and potato aphids. The results show that the Lamber's pan trap efficiency is highly influence by its location. Secondly, the aphid flight activity has been studied. We successfully identified the spread behaviour for cereal aphids with recognized primary migration during the end of June. Finally, the analysis of SET for first cereal aphid catches has been accomplished. Despite the fact that the differences at individual locations or the influence of the altitude cannot be proven, we were able to identify aphid species Rhopalosiphum padi as the aphid type requiring lowest $S E T$ for their first catch $(S E T=126.2)$.

Acknowledgements: Useful help with the statistical analysis and numerous invaluable advices of Petr Kulhánek are extremely appreciated. Thanks go to Zdeněk Pospíšil for helpful consultation concerning the utilization of suitable statistical methods. Jan Kmuníček is gratefully acknowledged for provision of necessary facility and logistics required for writing this article.

\section{References}

Remaudière G. \& Remaudière M. (1997): Catalogue des Aphididae du Monde. INRA. Paris. pp. 473.

Basky Z. \& Harrington R. (2000): Cereal aphid flight activity in Hungary and England compared by suction traps.- Anzeiger für Schädlingskunde, 73 (3): 70-74.

Blackman R.L. \& Eastop V.F. (2000): Aphids on the World's Crop. John Wiley and Sons. Chichester. pp. 466.

Honěk A. \& Kocourek F. (1990): Temperature and Development Time in Insects: A General Relationship between Thermal Constants.- Zool. Jb. Syst., 117: 401-439.

Juroch J. (2010): Ř́zení ochrany proti strupovitosti jabloně (Venturia inaequalis (Cke.) Wint.). Final study. Mendel University in Brno. 95 pp.

Macauly E.D.M., Tatchel G.M. \& Taylor L.R. (1988): The Rothamsted Insect Survey '12-metre' Suction Trap.- Bulletin of Entomological Research, 78(1): 121-128. 
Nedomová L. \& Milotová J. (2004): Collections of Cereal Crops in the Czech Republic. In Book of Abstracts of the Czech-Polish-Slovak Scientific Conference of Botanical Gardens "Biodiversity Conservation and Ecological Education - the Challenges in the United Europe". July 5-8, 2004. Cieszyn, Poland. pp. 34.

Reese J.C., Schwenke J.R., Lamont P.S. \& Zehr D.D. (1994): Importance and Quantification of Plant Tolerance in Crop Pest Management Programs for Aphids: Greenbug Resistance in Sorghum.- Journal of Agricultural Entomology, 11(3): 255-270.

Taylor L.R. (1962): The Absolute Efficiency of Insect Suction Traps.- Annals of Applied Biology, 50(3): 405421.

Author's address: Jana Patočková, Department of Crop Science, Breeding and Plant Medicine, Mendel University in Brno, 613 00, Brno, Czech Republic, e-mail: janaolbrecht@centrum.cz

\section{Monitoring mšic pomocí sacích pastí}

Studie se zabývá analýzou statistických dat monitorujících různé druhy mšic za použití dvou typů pastí sací pasti a Lambersovy misky. Studie je zaměřena na obilní mšice, jelikož obilniny jsou převažující zemědělskou plodinou v České republice. Primárně se studie zabývala následujícími druhy obilních mšic: mšice střemchová (Rhopalosiphum padi Linnaeus, 1758), kyjatka travní (Metopolophium dirhodum Walker, 1849), kyjatka osenní (Sitobion avenae Fabricius, 1775) a mšice zhoubná (Diuraphis noxia Kurdjumov, 1913). Okrajově byly do studie zahrnuty i tři druhy mšic bramborových: mšice řešetláková (Aphis nasturtii Kaltenbach, 1843), mšice broskvoňová (Myzus persicae Sulzer, 1776) and mšice chmelová (Phorodon humuli Schrank, 1801). Detailně byla prozkoumána řada aspektů životního cyklu mšic, jako je jejich četnost výskytu, letová aktivita a migrace. Bylo určeno chování obilních mšic během přeletu vykazující první migraci koncem června. Použití součtu efektivních teplot (SET) odhalilo mšici střemchovou jako druh s nejnižší hodnotou SET pro její záchyt $(S E T=126,2)$. Pro celou použitou datovou sadu nebyla nalezena korelace s nadmořskou výškou, tj. $\mathrm{s}$ lokalitou sběru primárních dat. 